\title{
Winter wheat health in different tillage methods
}

\section{Zdrowotność pszenicy ozimej w różnych wariantach uprawy roli}

\author{
Irena Małecka, Zuzanna Sawinska, Andrzej Blecharczyk, Marzena Dytman-Hagedorn
}

\section{Summary}

Fields experiments were conducted at the Brody Experimental Station in 2011-2012. The aim of studies was to determine the affect of tillage systems (conventional, reduced and direct drilling) on stem base, root, foliar and ears diseases severity on winter wheat. The incidence of stem base and root has been shown to increase under reduced tillage and direct drilling to compare with ploughing system. The conventional tillage increased the incidence of leaf and ear diseases of winter wheat in relation to the ploughingless tillage systems. Only the incidence of Drechslera tritici-repentis was significantly higher under reduced tillage and direct drilling than under conventional tillage in the first year of experiment.

Key words: winter wheat; stem base; root; leaf and ear diseases; tillage systems

\section{Streszczenie}

Doświadczenia przeprowadzono w latach 2011-2012 w Stacji Badawczej w Brodach. Celem badań była ocena wpływu systemów uprawy roli (tradycyjny, uproszczony, siew bezpośredni) na porażenie pszenicy ozimej przez choroby grzybowe podstawy źdźbła i korzeni oraz liści i kłosów. Większe nasilenie występowania chorób podstawy źdźbła i korzeni odnotowano w uproszczonej uprawie roli i siewie bezpośrednim w porównaniu do tradycyjnej uprawy roli. Uprawa płużna miała wpływ na wzrost liczby roślin z objawami chorób grzybowych na liściach i kłosach pszenicy ozimej w odniesieniu do systemów bezorkowych. Jedynie objawy brunatnej plamistości liści były istotnie większe w uproszczonej uprawie roli i siewie bezpośrednim niż w tradycyjnej uprawie roli w pierwszym roku badań.

Słowa kluczowe: pszenica ozima; choroby podstawy źdźbła i korzeni oraz liści i kłosa; systemy uprawy roli

\footnotetext{
Uniwersytet Przyrodniczy w Poznaniu

Katedra Agronomii

Dojazd 11, 60-632 Poznań

malecka@up.poznan.pl
} 


\section{Wstęp / Introduction}

W rolnictwie światowym w ostatnich 20 latach zauważalny jest kierunek ograniczania nakładów ponoszonych na produkcję $\mathrm{z}$ równoczesnym systematycznym wzrostem udziału zbóż w zasiewach. Głównym powodem tych zmian jest czynnik ekonomiczny, a ponadto zwiększenie nacisku na ochronę środowiska przyrodniczego. Jedną z dróg umożliwiającą zmniejszenie nakładów na produkcję rolną oraz poprawę zachowawczości środowiska jest odejście od uprawy orkowej na rzecz uprawy uproszczonej (powierzchniowej) lub siewu bezpośredniego, w którym całkowicie rezygnuje się z uprawy roli, a część resztek roślinnych pozostaje na powierzchni pola (Cook 2001; Paulitz 2006; Korbas i wsp. 2008). Ponadto uproszczenia w uprawie roli łączy się często $\mathrm{z}$ uproszczeniami w zmianowaniach, w których zboża uprawiane są po sobie, co prowadzi do większej presji patogenów wywołujących choroby podsuszkowe. Patogeny wywołujące choroby podstawy źdźbła i korzeni przeżywają na resztkach pożniwnych zbóż oraz na korzeniach chwastów z rodziny traw, dlatego też systemy bezorkowe mogą sprzyjać ich występowaniu (Elen 2003; Paulitz 2006; Korbas 2008; Korbas i wsp. 2008; Janusauskaite i Ciuberkis 2010). Ponadto resztki roślinne na powierzchni pola utrzymują korzystną wilgotność i temperaturę w warstwie gleby 10-15 cm, gdzie patogeny sa najbardziej aktywne (Bockus i Shroyer 1998; Cook 2001). Choroby podsuszkowe w zbożach powodowane są przez jednego lub kompleks grzybów takich, jak: Oculimacula spp., Rizoctonia spp., Gaeumannomyces graminis var. tritici lub Fusarium spp. (Korbas i wsp. 2008). Fuzaryjna zgorzel podstawy źdźbła i korzeni, której sprawcą jest G. graminis var. tritici uważana jest za jedną z głównych chorób pszenicy w intensywnych systemach gospodarowania. Wyniki badań dotyczące wpływu systemów uprawy roli na występowanie chorób podsuszkowych nie są jednak jednoznaczne (Weber i wsp. 2001; Boligłowa i Lepiarczyk 2006; Parylak 2006; Jørgensen i Olsen 2007; Korbas i wsp. 2008; Smagacz 2008; Faltyn i Kordas 2009; Pląskowska i wsp. 2009; Majchrzak i wsp. 2010; Weber i Kita 2012).

Celem badań była ocena wpływu różnych sposobów uprawy roli na zdrowotność pszenicy ozimej. Dokładne poznanie powyższego problemu umożliwi wybór właściwej strategii ochrony przeciwko sprawcom chorób.

\section{Materiały i metody / Materials and methods}

Badania przeprowadzono w latach 2011-2012 w oparciu o statyczne doświadczenie polowe założone w 1999 roku w Katedrze Agronomii Uniwersytetu Przyrodniczego w Poznaniu (Zakład Doświadczalno-Dydaktyczny Brody). Doświadczenie założono jako jednoczynnikowe w układzie niezależnym, w czterech powtórzeniach. Pszenicę ozimą odmiany Turkis uprawiano w 4-polowym płodozmianie: groch, pszenica ozima, jęczmień jary, pszenżyto ozime. Czynnikiem doświadczalnym były różne sposoby uprawy roli: uprawa tradycyjna (podorywka + orka siewna + agregat uprawowy), uprawa uproszczona (agregat ścierniskowy), siew bezpośredni w ściernisko. Doświad- czenie zlokalizowano na glebie płowej o składzie granulometrycznym piasków gliniastych lekkich i mocnych, klasy bonitacyjnej IIIb-IVa kompleksu żytniego bardzo dobrego i dobrego. Według klasyfikacji FAO/WRB (Food and Agriculture Organization/World Reference Base) gleby takie są klasyfikowane jako Albic Luvisols (Typic Hapludalfs według Soil Taxonomy). W fazie strzelania w źdźbło pszenicy przeprowadzono zabieg przy użyciu fungicydów: Duet Ultra 497 SC (epoksykonazol + tiofanat metylu) w 2011 roku w dawce 0,6 1/ha oraz Falcon 460 EC (tebukonazol + spiroksamina + triadimentol) w 2012 roku w dawce $0,61 /$ ha.

Ocenę porażenia pszenicy ozimej przez choroby podstawy źdźbła i korzeni przeprowadzono wzrokowo w fazie dojrzałości mlecznej (BBCH 73), na postawie występujących na dolnych partiach źdźbeł charakterrystycznych dla nich plam, przebarwień i nekroz. Następnie dla każdej z chorób obliczono odsetek roślin z objawami, bez względu na ich nasilenie oraz indeks porażenia w skali 0-400, wyliczony według Windelsa i Wiersma (1992). W doświadczeniu w fazie dojrzałości wodnej ziarna (BBCH 70-71) oznaczono ponadto procent powierzchni liści i kłosów z objawami chorób grzybowych.

Warunki pogodowe w latach prowadzenia badań były zróżnicowane. W sezonie 2009/2010 suma opadów w miesiącach wiosennych (marzec, kwiecień i maj) przewyższała średnie za wielolecie, a ponadto średnia temperatura powietrza była wyższa niż w wieloleciu. Można uznać więc ten sezon wegetacyjny za sprzyjający występowaniu chorób grzybowych. W drugim roku badań odnotowano niższe opady przy wyższej średniej dobowej temperaturze powietrza w okresie wiosennej wegetacji pszenicy ozimej, co nie sprzyjało aktywności patogenów. Uzyskane wyniki poddano ocenie statystycznej z zastosowaniem analizy wariancji, po uprzednim przekształceniu wyników według wzoru

$$
\mathrm{y}=\arcsin \sqrt{ } \mathrm{x}
$$

Istotność zróżnicowania wyników oceniono testem Fishera-Snedecora na poziomie istotności $p=0,05$, natomiast badanie istotności różnic pomiędzy średnimi szacowano testem Tukeya.

\section{Wyniki i dyskusja / Results and discussion}

W obu latach badań w dojrzałości mlecznej ziarna pszenicy ozimej odnotowano większą liczbę roślin z objawami fuzarioz (Fusarium spp.) i łamliwości źdźbeł (Oculimacula spp.), aniżeli zgorzeli podstawy źdźbła i korzeni, której sprawcą jest grzyb G. graminis (tab. 1). Bezpłużna technologia uprawy roli przyczyniła się do istotnego wzrostu aktywności patogenów, sprawców wywołujących objawy chorób podstawy źdźbła i korzeni w porównaniu do tradycyjnej (orkowej) uprawy. Obserwowano to zarówno $\mathrm{w}$ odniesieniu do liczby roślin z objawami chorób podsuszkowych, jak i do wyliczonego wskaźnika porażenia. W pierwszym roku badań występowanie powyższych sprawców chorób obserwowano na 13,8 do $33,9 \%$ roślin pszenicy uprawianej tradycyjnie, 
Tabela 1. Występowanie chorób podstawy źdźbła i korzeni na pszenicy ozimej

Table 1. Occurrence on stem base and root diseases on winter wheat

\begin{tabular}{|c|c|c|c|c|c|c|}
\hline \multirow{2}{*}{$\begin{array}{l}\text { Sposób uprawy roli } \\
\text { Tillage methods }\end{array}$} & \multicolumn{2}{|c|}{ G. graminis } & \multicolumn{2}{|c|}{ Oculimacula spp. } & \multicolumn{2}{|c|}{ Fusarium spp. } \\
\hline & $2010 / 2011$ & $2011 / 2012$ & $2010 / 2011$ & $2011 / 2012$ & $2010 / 2011$ & $2011 / 2012$ \\
\hline \multicolumn{7}{|c|}{ \% porażonych źdźbeł - \% of affected stems } \\
\hline $\begin{array}{l}\text { Tradycyjna } \\
\text { Conventional }\end{array}$ & 13,8 & 6,5 & 30,3 & 7,5 & 33,9 & 21,0 \\
\hline $\begin{array}{l}\text { Uproszczona } \\
\text { Reduced }\end{array}$ & 29,0 & 19,5 & 47,2 & 16,0 & 56,3 & 39,0 \\
\hline $\begin{array}{l}\text { Siew bezpośredni } \\
\text { Direct drilling }\end{array}$ & 43,2 & 20,0 & 60,3 & 20,0 & 72,4 & 46,5 \\
\hline $\operatorname{NIR}(0,05)-\operatorname{LSD}(0.05)$ & 10,6 & 8,5 & 12,6 & 8,4 & 13,3 & 10,6 \\
\hline \multicolumn{7}{|c|}{ Indeks porażenia - Infection index [0-400] } \\
\hline $\begin{array}{l}\text { Tradycyjna } \\
\text { Conventional }\end{array}$ & 23,8 & 6,5 & 41,2 & 8,5 & 53,9 & 27,0 \\
\hline $\begin{array}{l}\text { Uproszczona } \\
\text { Reduced }\end{array}$ & 61,0 & 30,3 & 78,3 & 20,2 & 120,2 & 63,0 \\
\hline $\begin{array}{l}\text { Siew bezpośredni } \\
\text { Direct drilling }\end{array}$ & 91,0 & 38,9 & 90,4 & 28,5 & 198,6 & 78,5 \\
\hline NIR $(0,05)-\operatorname{LSD}(0.05)$ & 23,1 & 10,5 & 21,3 & 16,2 & 21,4 & 17,9 \\
\hline
\end{tabular}

z zastosowaniem pługa. Uprawa uproszczona przyczyniła się do wzrostu liczby roślin z objawami chorób podstawy źdźbła i korzeni do poziomu 29,0-56,3\%, natomiast siew bezpośredni do 43,2-72,4\%. W drugim roku badań wpływ sposobów uprawy roli na porażenie pszenicy ozimej przez sprawców chorób podstawy źdźbła i korzeni był podobny, jednak odsetek zainfekowanych roślin kształtował się na znacznie niższym poziomie, co wynikało z odmiennego przebiegu pogody w latach badań.

Analizując nasilenie występowania chorób podsuszkowych wyrażone wyliczonym indeksem porażenia można stwierdzić, iż w tradycyjnej uprawie roli wskaźnik ten mieścił się w zakresie porażenia nieznacznego, w którym rośliny uznaje się jako rośliny zdrowe. W systemach bezorkowych indeks porażenia był istotnie większy, jakkolwiek w drugim roku badań był on również na poziomie poniżej 75 (porażenie nieznaczne), a jedynie w odniesieniu do fuzarioz kształtował się w zakresie porażenia słabego $\mathrm{w}$ przypadku uprawy pszenicy ozimej w siewie bezpośrednim. W sezonie wegetacyjnym 2010/2011, w którym panowały bardziej sprzyjające warunki pogodowe dla rozwoju chorób grzybowych, indeks porażenia chorobami kształtował się w zakresie porażenia słabego, a jedynie w siewie bezpośrednim można zakwalifikować go do porażenia średniego w odniesieniu do grzybów powodujących fuzariozę kłosów.

Systemy uprawy roli, przez zmianę właściwości gleby, mogą wpływać na fuzaryjną zgorzel podstawy źdźbła i korzeni. W uproszczonej uprawie roli, zwłaszcza w siewach bezpośrednich, pozostające na powierzchni pola resztki roślinne oraz większa wilgotność gleby, przy jednocześnie niższej temperaturze sprzyjają występowaniu chorób podstawy źdźbła i korzeni (Bockus i Shroyer 1998; Cook 2001; Bailey i Lazarovits 2003; Elen 2003; Paulitz 2006). Z drugiej strony, system siewu bezpośredniego sprzyja akumulacji substancji organicznej w wierzchniej warstwie gleby i zwiększeniu aktywności biologicznej, co może ograniczać populację patogenów w glebie (Krupinsky i wsp. 2002). Stąd też wyniki badań dotyczące wpływu systemów uprawy roli, zwłaszcza siewu bezpośredniego, na występowanie tych chorób są ciągle niejednoznaczne. Notowano w bezorkowych systemach uprawy roli zarówno większe porażenie podstawy źdźbła i korzeni zbóż (Sawinska i Małecka 2005; Boligłowa i Lepiarczyk 2006; Kordas 2006; Faltyn i Kordas 2009), jak i mniejsze porażenie (Bailey i wsp. 1992; Weber i wsp. 2001; Smagacz 2008), bądź brak większego wpływu systemów uprawy na zróżnicowanie występowania tych chorób (Pląskowska i wsp. 2002; Parylak 2006).

W przeprowadzonym doświadczeniu wykonano także ocenę porażenia liści i kłosów w fazie dojrzałości mlecznej. Na liściach flagowych stwierdzono objawy mączniaka prawdziwego (Blumeria graminis), septoriozy paskowanej (Stragonospora tritici), rdzy brunatnej (Puccinia recondita sp. tritici) i brunatnej plamistości liści (Drechslera triticirepentis). Kłosy pszenicy ozimej porażane były przez grzyby rodzaju Fusarium oraz przez grzyb Stragonospora nodorum, sprawcę septoriozy plew (tab. 2, 3).

Występowanie chorób na liściach i kłosach pszenicy ozimej mieściło się w zakresie od 0,8 do $19,9 \%$ i było zróżnicowane $\mathrm{w}$ większym stopniu $\mathrm{w}$ latach badań niż w zależności od sposobów uprawy roli. Zdaniem niektórych autorów wpływ warunków pogodowych na występowanie i nasilenie chorób grzybowych w zbożach jest większy aniżeli czynnik badawczy (Lori i wsp. 2009; Janusauskaite i Ciuberkis 2010; Horoszkiewicz-Janka i wsp. 2012). W omawianym doświadczeniu większe nasilenie chorób na liściach pszenicy obserwowano w sezonie 2010/2011, charakteryzującym się większymi opadami, szczególnie wiosną, niż w sezonie 2011/2012. Zdaniem Colbacha i wsp. (1999) występowanie D. triticirepentis i $S$. tritici zależy głównie od warunków pogodowych panujących w okresie wegetacji pszenicy ozimej, szczególnie wysokich opadów. 
Tabela 2. Procent porażenia powierzchni liści pszenicy ozimej przez patogeny

Table 2. Percentage of winter wheat leaf area infected by pathogens fungi

\begin{tabular}{l|c|c|c|c|c|c|c|c}
\hline \multirow{2}{*}{$\begin{array}{c}\text { Sposób uprawy roli } \\
\text { Tillage systems }\end{array}$} & \multicolumn{7}{c}{ Liść flagowy - Flag leaf } \\
\cline { 2 - 10 } & $2010 / 2011$ & $2011 / 2012$ & $2010 / 2011$ & $2011 / 2012$ & $2010 / 2011$ & $2011 / 2012$ & $2010 / 2011$ & $2011 / 2012$ \\
\cline { 2 - 9 } & 10,1 & 3,7 & 18,3 & 10,3 & 19,1 & 2,9 & 7,3 & 3,4 \\
\hline $\begin{array}{l}\text { Uprawa tradycyjna } \\
\text { Conventional tillage }\end{array}$ & 7,3 & 0,9 & 12,2 & 8,7 & 18,2 & 3,2 & 9,7 & 2,9 \\
\hline $\begin{array}{l}\text { Uprawa uproszczona } \\
\text { Reduced tillage }\end{array}$ & 6,9 & 0,8 & 12,9 & 8,2 & 15,3 & 2,6 & 13,1 & 3,1 \\
\hline $\begin{array}{l}\text { Siew bezpośredni } \\
\text { Direct drilling }\end{array}$ & 2,1 & 1,3 & 2,5 & 1,9 & 1,4 & r.n. & 1,9 & r.n. \\
\hline $\begin{array}{l}\text { NIR (0,05) } \\
\text { LSD (0.05) }\end{array}$ & & & & & \multirow{2}{*}{ S. tritici } \\
\hline
\end{tabular}

r.n. - różnice nieistotne - not significant differences

Tabela 3. Procent porażonej powierzchni kłosa pszenicy ozimej przez patogeny

Table 3. Percentage of winter wheat ear area infected by pathogens fungi

\begin{tabular}{l|c|c|c|c}
\hline \multirow{2}{*}{$\begin{array}{c}\text { Sposób uprawy roli } \\
\text { Tillage systems }\end{array}$} & \multicolumn{4}{|c}{ Kłos - Ear } \\
\cline { 2 - 5 } & \multicolumn{2}{|c}{ Fusarium spp. } & \multicolumn{2}{c}{ S. nodorum } \\
\cline { 2 - 5 } & $2010 / 2011$ & $2011 / 2012$ & $2010 / 2011$ & $2011 / 2012$ \\
\hline Uprawa tradycyjna - Conventional tillage & 19,9 & 2,4 & 8,7 & 2,4 \\
\hline Uprawa uproszczona - Reduced tillage & 18,2 & 1,9 & 8,1 & 2,7 \\
\hline Siew bezpośredni - Direct drilling & 17,6 & 1,9 & 1,3 & r.n. \\
\hline NIR $(0,05)$ - LSD $(0.05)$ & 1,4 & r.n. & & \\
\hline
\end{tabular}

r.n. - różnice nieistotne - not significant differences

Analiza wariancji wykazała istotny wpływ sposobów uprawy roli na porażenie liści chorobami grzybowymi (tab. 2). W obu latach badań silniejsze porażenie liści pszenicy ozimej mączniakiem prawdziwym, rdzą brunatną i septoriozą paskowaną odnotowano w tradycyjnej uprawie roli niż w uproszczonej i siewie bezpośrednim. Moszczyńska i Pląskowska (2005) uważają, że uprawa płużna stwarzając pszenicy dobre warunki rozwoju, między innymi większe zagęszczenie łanu, zapewnia jednocześnie sprzyjające warunki dla wzrostu zagrożenia ze strony patogenów. Zdaniem powyższych autorów patogeny bezwzględne (B. graminis i $P$. recondita $\mathrm{sp}$. tritici) preferują rośliny w dobrej kondycji. Odwrotne zależności zaobserwowano $\mathrm{w}$ odniesieniu do brunatnej plamistości liści, gdyż istotnie większą porażoną powierzchnię liści flagowych pszenicy obserwowano w uprawie uproszczonej i siewie bezpośrednim niż w uprawie płużnej. Można to tłumaczyć tym, iż zarodnikowanie sprawcy tej choroby odbywa się w dużej mierze na resztkach pożniwnych, co może zwiększać ryzyko infekcji w systemach bezorkowych, w których duża część resztek roślinnych pozostaje na powierzchni pola.

Kłosy pszenicy ozimej porażane były w większym stopniu przez grzyby rodzaju Fusarium, aniżeli przez grzyb S. nodorum. Grzyby rodzaju Fusarium infekuja wszystkie gatunki zbóż, jednak pszenica jest najbardziej podatna na fuzariozę kłosa oraz akumuluje największe ilości deoksyniwalenolu (DON) w ziarnie (Miedaner i wsp. 2001). Występowanie chorób grzybowych na kłosach pszenicy było uzależnione od sposobu uprawy roli jedynie w pierwszym roku badań (tab. 3). Istotnie większą zainfekowaną powierzchnię odnotowano w tradycyjnej uprawie roli w porównaniu do uproszczonej uprawy i siewu bezpośredniego. W drugim roku badań, w którym występowanie fuzariozy kłosów i septoriozy plew było nieznaczne (1,9-2,7\%), nie obserwowano istotnego ich zróżnicowania pod wpływem sposobów uprawy roli.

Podobne rezultaty uzyskali Elen (2003) oraz Jørgensen i Olsen (2007). Z kolei Pląskowska i wsp. (2009) stwierdzili odmienny wpływ uprawy roli na porażenie liści i kłosów pszenicy ozimej w latach badań, natomiast inni autorzy nie wykazali istotnego wpływu sposobów uprawy roli na występowanie patogenów na liściach i kłosach pszenicy (Lori i wsp. 2009; Majchrzak i wsp. 2010; Horoszkiewicz-Janka i wsp. 2012).

\section{Wnioski / Conclusions}

1. Pszenica ozima w uproszczonej uprawie roli i siewie bezpośrednim narażona była w większym stopniu na choroby podsuszkowe niż w tradycyjnej (płużnej) uprawie roli.

2. Tradycyjna uprawa roli sprzyjała występowaniu chorób grzybowych na liściach i kłosach pszenicy ozimej.

Badania finansowane ze środków MNiSW jako projekt badawczy nr N N310 025939. 


\section{Literatura / References}

Bailey K.L., Mortensen K., Lafond G.P. 1992. Effects of tillage systems and crop rotations on root and foliar disease of wheat, flax, and peas in Saskatchewan. Can. J. Plant Sci. 72: 583-591.

Bailey K.L., Lazarovits G. 2003. Suppressing soil-borne diseases with residue management and organic amendments. Soil Till. Res. 72: $169-180$.

Bockus W.W., Shroyer J.P. 1998. The impact of reduced tillage on soilborne plant pathogens. Annu. Rev. Phytopathol. 36: 485-500.

Boligłowa E., Lepiarczyk A. 2006. Wpływ sposobu uprawy roli na zdrowotność podstawy źdźbła pszenicy ozimej. [The influence of tillage system on winter wheat stem base healthiness]. Prog. Plant Prot./Post. Ochr. Roślin 46 (2): 530-532.

Colbach N., Meynard J.M., Duby C., Huet P. 1999. A dynamic model of the influence of rotation and crop management on the disease development of eyespot. Proposal of cropping systems with low disease risk. Crop Prot. 18: 451-461.

Cook R.J. 2001. Management of wheat and barley root diseases in modern farming systems. Austral. Plant Pathol. 30 (2): $119-126$.

Elen O. 2003. Long-term experiments with reduced tillage in spring cereals. III. Development of leaf diseases. Crop Prot. $22: 65-71$.

Faltyn U., Kordas L. 2009. Wpływ różnych systemów uprawy roli oraz zróżnicowanego nawożenia fosforowo-potasowego na zdrowotność pszenicy ozimej. [The effect of varying tillage system and different phosphorus and potassium fertilization on health status of spring wheat]. Prog. Plant Prot./Post. Ochr. Roślin 49 (1): 393-396.

Horoszkiewicz-Janka J., Jajor E., Korbas M. 2012. Występowanie chorób pszenicy ozimej w zależności od wybranych czynników agrotechnicznych. [Prevalence of winter wheat diseases depending on selected agrotechnical factors]. Prog. Plant Prot./Post. Ochr. Roślin 52 (4): 998-1004.

Janusauskaite D., Ciuberkis S. 2010. Effect of different soil tillage and organic fertilizers on winter triticale and spring barley stem base diseases. Crop Prot. 29: 802-807.

Jørgensen L.N., Olsen L.V. 2007. Control of tan spot (Drechslera tritici-repentis) using cultivar resistance, tillage methods and fungicides. Crop. Prot. 26: 1606-1616.

Korbas M. 2008. Epidemiologia łamliwości źdźbła pszenicy ozimej w Polsce. Rozpr. Nauk. Inst. Ochr. Roślin, Poznań 18, 68 ss.

Korbas M., Horoszkiewicz-Janka J., Jajor E. 2008. Uproszczone systemy uprawy a występowanie sprawców chorób. [Simplified systems of soil management in relation to the occurrence of disease casual agents]. Prog. Plant Prot./Post. Ochr. Roślin 48 (4): $1431-1438$.

Kordas L. 2006. Porażenie pszenicy ozimej przez Gaeumannomyces graminis uprawianej tradycyjnie i w siewie bezpośrednim. [Infection of winter wheat by Gaeumannomyces graminis under traditional tillage and direct sowing]. Prog. Plant Prot./Post. Ochr. Roślin 46 (2): 708-711.

Krupinsky J.M., Bailey K.L., McMullen M.P., Gossen B.D., Turkington T.K. 2002. Managing plant disease risk in diversified cropping systems. Agron. J. 94: 198-209.

Lori G.A., Sisterna M.N., Sarandón S.J., Rizzo I., Chidichimo H. 2009. Fusarium head blight in wheat: Impact of tillage and other agronomic practices under natural infection. Crop Prot. 28: 495-502.

Majchrzak L., Sawinska Z., Skrzypczak G. 2010. Zdrowotność pszenicy jarej w zależności od systemu uprawy roli. [Healthiness of spring wheat depending on soil tillage system]. Prog. Plant Prot./Post. Ochr. Roślin 50 (2): 931-934.

Miedaner T., Reinbrecht C., Lauber U., Schollenberger M., Geiger H.H. 2001. Effects of genotype-environment interaction on deoxynivalenol accumulation and resistance to Fusarium head blight in rye, triticale and wheat. Plant Breeding 120: 97-105.

Moszczyńska E., Pląskowska E. 2005. Ocena zdrowotności pszenicy ozimej uprawianej tradycyjnie, w siewie bezpośrednim oraz w siewie bezpośrednim z wsiewką koniczyny białej. Acta Agrobot. 58 (2): 227-286.

Parylak D. 2006. Uprawa pszenicy ozimej po sobie z zastosowaniem uproszczeń w uprawie roli a występowanie chorób podstawy źdźbła. [Winter wheat continuous cropping under reduced tillage and an versus occurrence of stem base diseases]. Prog. Plant Prot./Post. Ochr. Roślin 46 (2): 509-511.

Paulitz T.C. 2006. Low input no-till cereal production in the Pacific Nortwest of the U.S.: the challenges of root diseases. Eur. J. Plant Pathol. 115: 271-281.

Pląskowska E., Matkowski K., Moszczyńska E., Kordas L. 2002. Zdrowotność podstawy źdźbła pszenicy jarej w uprawie tradycyjnej i siewie bezpośrednim przy dwóch poziomach nawożenia azotem. Acta Sci. Pol., Agricultura 1 (1): 131-138.

Pląskowska E., Moszczyńska E., Matkowski K., Kordas L. 2009. Wpływ sposobu uprawy roli na zdrowotność i plonowanie pszenicy ozimej. [The effect of soil tillage system on health status and grain yield of winter wheat]. Prog. Plant Prot./Post. Ochr. Roślin 49 (4): 2058-2062.

Sawinska I., Małecka I. 2005. Dynamika rozwoju chorób podstawy źdźbła i korzeni pszenicy ozimej w różnych systemach uprawy roli. [Dynamic of winter wheat foot and root diseases under different tillage systems]. Prog. Plant Prot./Post. Ochr. Roślin 45 (2): $1061-1064$.

Smagacz J. 2008. Wpływ uproszczeń w uprawie roli na występowanie chorób podstawy źdźbła, zachwaszczenie łanu i plonowanie pszenicy ozimej. [Influence of soil tillage simplification on occurrence of stem base diseases, weed infestation and yielding of winter wheat]. Prog. Plant Prot./Post. Ochr. Roślin 48 (4): 1475-1478.

Weber R., Hryńczuk B., Runowska-Hryńczuk B., Kita W. 2001. Influence of the mode of tillage on diseases of culm base in some winter wheat varieties, oats and spring wheat. J. Phytopathol. 149: 185-188.

Weber R., Kita W. 2012. Występowanie kompleksu chorób podstawy źdźbła kilku odmian pszenicy ozimej w zależności od systemu uprawy roli i wysokości ścierni. [Occurrence of the complex of stem-base diseases in few winter wheat cultivars depending farming systems and stubble length]. Prog. Plant Prot./Post. Ochr. Roślin 52 (2): 323-326.

Windels C., Wiersma J. 1992. Incidence of Bipolaris and Fusarium on subcrown internodes of spring barley and wheat grown in continuous conservation tillage. Phytopathol. 82: 699-705. 